Yaz-2016 Cilt:15 Say1:58 (903-916) Summer-2016 Volume:15 Issue:58

\title{
PHYSIOLOGICAL MEASUREMENT OF THE PROCESS OF PERSPECTIVE SHIFT IN THE MENTAL IMAGERY OF TEST ANXIETY
}

\author{
SINAV KAYGISININ ZİHINSEL CANLANDIRMASINDA AÇI DEĞİŞİKLİĞİ \\ SÜRECINNIN FİYOLOJIK ÖLÇÜMÜ
}

\section{DOI:10.17755/esosder.38688}

\author{
A.Kadir ÖZER ${ }^{1}$ \\ Cemile Ekin EREMSOY ${ }^{2}$ \\ Emel KROMER $^{3}$
}

\begin{abstract}
Research on the relative effects of imagining an event from a field vs. observer perspective on emotional experience has mostly relied on the subjective and retrospective self-reports. The main goal of the present study was to investigate the effects of the process of perspective shift on the experience of test anxiety by using physiological responses. Forty seven participants were asked to imagine themselves in a test anxiety situation. Once the original perspective (field or observer) was established, they shifted to the other perspective and then back to the original one. Results indicated that heart rate decreased significantly when those starting with a field perspective shifted to an observer perspective and increased significantly when shifted back to the field perspective. Investigation of the relative effects of perspective shift in high vs. low groups in emotional dispositions might further advance understanding whether perspective adherence might be considered as a legitimate trait.
\end{abstract}

Keywords: Mental imagery, imagery perspective, physiological measures, test anxiety

\section{Öz}

Bir olayın göz veya dış açı ile zihinde canlandırılmasının duygusal yaşantılar üzerindeki etkisi ile ilgili araştırmaların çoğu, sübjektif ve geriye dönük bildirimlerine dayanmaktadır. Bu araştırmanın temel amacı, fizyolojik tepkileri kullanarak canlandırma açısı değişikliğine dair sürecin sınav kaygısı üzerindeki etkisini incelemektir. 47 katılımcıdan kendilerini sınav kaygısı yaşadıkları bir ortamda zihinsel olarak canlandırmaları istenmiştir. Zihinsel canlandırma yaptıkları orijinal açı (göz veya dış) saptandıktan sonra, diğer açıya geçmeleri ve sonrasında tekrar orijinal açıya geri dönmeleri istenmiş̧ir. Göz açısı ile canlandırmaya başlayan katılımcıların dış açıya geçtiklerinde kalp atı̧̧larında anlamlı düzeyde düşüş ve sonrasında yeniden göz açısına döndüklerinde ise yine anlamlı düzeyde yükseliş olduğu görülmüştür. Canlandırma açı değişikliğinin duygular üzerindeki etkisinin bahsi geçen duyguyu yüksek veya düşük düzeyde yaşayan katılımcıların oluşturduğu grupları karşılaştırma yoluyla incelemek, canlandırma açısı yöneliminin kişisel bir özellik sayılıp sayılmayacağı konusuna 1 şı tutacaktır.

Anahtar Kelimeler: Zihinsel canlandırma, canlandırma açısı, fizyolojik ölçümler, sınav kaygısı

\footnotetext{
1 ozer.akadir@gmail.com

${ }^{2}$ Yrd.Doç.Dr., Doğuş Üniversitesi, ekineremsoy@gmail.com

3 emel.kromer@gmail.com
} 


\section{Introduction}

Although imagery has been employed in psychotherapy as an intervention tool for a long time, it has only drawn attention as an admissible variable for empirical exploration during past few decades. The role of imagery in the activation of mechanisms that control physiological processes has been demonstrated by a number of studies. The effects of visualizing an emotionally loaded event have been shown to result in increased galvanic skin response, heart and breathing rates much like encountering the actual event (Lang, 1979; Vrana, Cuthbert, \& Lang, 1986; Miller, Levin, Kozak, Cook, McLean, \& Lang, 1987; Lang, Bradley, \& Cuthbert, 1998). The concurrent emergence of cognitive neuroscience and its technologies seem to have reinforced a new interest in the study of imagery. Technologies like positron emission tomography and functional magnetic resonance imaging have given the researchers the opportunity to understand that mental imagery effects neural structures similar to that of actual perception, motor behavior and emotion experience (e.g., Farah, 1984; Chatterjee \& Southwood, 1995; Kosslyn, Thompson, Kim, \& Albert, 1995; Schacter, Addis, \& Buckner, 2007).

The effects of thought processes on the formation of emotional experience have been a major focus of attention especially in the domain of cognitive psychotherapy. The impact of verbal processing of external events on emotions have been delineated in numerous studies (e.g., Beck, 1985; Mahoney, 1993; Dadds, Bovbjerg, Reed, \& Cutmore, 1997); and as Mahoney has most succinctly declared that the validation of thought processes as legitimate mediators of emotions has been the most notable end product of the "cognitive revolution" (1993, p. 187). The interest in the study of imagery can be regarded as an extension of this revolution. Research during the past decade has focused on the relative effectiveness of verbal and visual processing of stimuli. Results seem to signify that imagination of an event might have a more distinct impact on the generation of emotions as opposed to verbal processing of the same event (e.g., O'Craven \& Kanwisher, 2000; Öhman \& Mineka, 2001; Mathews \& MacLeod, 2002; Hirsch, Clark, \& Mathews, 2006; Holmes, Mathews, Dalgleish, \& Mackintosh, 2006). In the study conducted by Holmes et al. (2006) the subjects were asked to verbally and visually process a situation in that they were prone to experience anxiety. As stated by the researchers, results provide evidence that "...imagery might have a more powerful impact on emotional responses than verbal processing of the same material" (p. 245).

Research on autobiographical memory has produced rather conducive results in understanding the role of imagery in recollecting past events. Nigro and Neisser (1983) were among the first to systematically investigate and emphasize the perspective adopted in imagining past personal events. In their frequently cited study, they defined two distinct angles of imagination of a past personal event: observer and field. In observer perspective, the person looks at the situation from an external point and sees oneself from the outside; but in field perspective the scene appears as it was in the original situation and one does not see oneself in the imagined scene.

Nigro and Neisser (1983) study revealed a number of results that seem to have opened a pathway for further research. The results can be highlighted as (1) observer perspective was more likely to be found for memories associated with high levels of emotion and high levels of self-awareness; (2) there was a significant inclination to a field perspective when individuals were asked to recall the feelings associated with a particular event; (3) when individuals imagined memories of events in their objective circumstances, the imagery perspective was more likely to be an observer. In later years, McIsaac and Eich (2002) used a forced perspective procedure in that they asked the participants to verbally describe their 
memories from either an observer or field perspective. They reported that while memories narrated from an observer perspective focused more on the objective circumstances, memories narrated from a field perspective focused more on emotional states. Similarly, D'Argembeau, Comblain, and van der Linden (2003) found that emotional memories were more likely to be remembered from a field perspective than were neutral memories. In contrast, Robinson and Swanson (1993) found that high- and low-intensity memories were equally likely to be remembered from an observer or a field perspective, but shifting from field to observer perspective resulted in reduced emotional intensity of the memory and reduced awareness of feelings.

Social anxiety seems to have received a relatively high degree of attention in conjunction with imagery perspective (Wells, Clark, \& Ahmad, 1998; Coles, Turk, Heimberg, \& Fresco, 2001; Libby \& Eibach, 2002; Spurr \& Stopa, 2003; Hackman \& Holmes, 2004; McIsaac \& Eich, 2004; Bywaters, Andrade, \& Turpin, 2004; Berntsen \& Rubin, 2006; Sutin \& Robins, 2008). Collectively, the results of these studies appear to indicate that individuals high in social anxiety tend to recall the instances wherein they experienced anxiety from an observer perspective more frequently than those low in social anxiety. Moreover, this tendency seems to disappear in the recollection of those events associated with low to moderate levels of social anxiety.

Investigation of imagery perspective with other emotions is rare. Lemogne et al. (2006) and Bergouignan et al. (2008) have studied recollection or negative and positive memories of depressed patients. The results seem to implicate that there is a marked tendency among depressed patients to recall positive memories from a field perspective as opposed to observer perspective. In another study by Kross, Ayduk, and Mischel (2005), the emotion of anger was explored and the results were discussed by the authors as suggesting that switching to an observer point of view might be selected to cool down the emotion of anger.

Emotional experiences evoked as a function of imagery have been measured in a number of studies (e.g., Lang, Melamed, \& Hart, 1970; King, 1973; Lichstein \& Lipshitz, 1982; Lang, 1985; Lang et al., 1998; Vrana et al., 1986; Bywaters et al., 2004). In most of these studies the focus of attention has been anxiety and the results seem to confirm that elevated level of anxiety is associated with elevated heart rate, galvanic skin response, electroencephalography, and electromyography. As an example, Bywaters et al. (2004) compared the effects of imagining intrusive and non-intrusive memories and have found that those who imagined intrusive memories produced significantly higher level of heart rate and zygomotor electromyography.

Since the onset of explorations regarding the relative effects of imagery perspective on emotions by Nigro and Neisser (1983) study, there have been numerous research where the influence of perspective shift has been studied (e.g., Frank \& Gilovich, 1989; Wells et al., 1998; Coles et al., 2001; McIsaac \& Eich, 2004; Berntsen \& Rubin, 2006; Hirsch et al., 2006; Lemogne et al., 2006). However, in almost all of these studies measurement of perspective shift depended on the retrospective subjective evaluations of the participants. Hence the process of emotional change as a function of perspective shift has not yet been demonstrated by physiological measures. The need for such an exploration has been stated by a number of researchers (Kross et al., 2005; Holmes \& Mathew, 2005).

The main goal of the present study was to explore the process of emotional change as a function of shift in imagery perspective through physiological measures of heart rate and surface electromyography. The emotion chosen was test anxiety, a relatively more situation specific form of anxiety. It was hypothesized that those who originally imagined themselves in a test situation from a field perspective will display lower levels in the aforementioned 
physiological measures as they shifted to an observer angle. Conversely, those shifting their imagery from an observer angle to a field perspective will exhibit increasing physiological responses as an indication of emotional intensity.

\section{Method}

\section{Participants}

A total of 732 undergraduate students from Doğuş University were given a battery of inventories. In order to rule out the possible effects of being extremely low or high in any of these emotional dispositions, the participants of the present study were derived from those whose scores fell between the 20th (included) and 80th (included) percentiles. A total of 226 students (Trait Anxiety Inventory $M[S D]=39.49$ [6.48]) were detected as eligible for the study. Among those, 100 were randomly selected and invited to participate in the experimental phase of the study. Of these participants, 48 did not show up and the data of a total of 5 participants were excluded from the study due to past or current cardiovascular problems and outlier analysis. In the final analysis a total of 47 subjects, whose ages ranged between 18 and 32, participated in the experiment. Specifically, there were 22 (47\%) females with a mean of age $21.36(S D=3.62)$ and $25(53 \%)$ males with a mean of age $21.63(S D=$ 2.62). Among females, 13 (59\%) reported the original imagery perspective as the field perspective, and $9(41 \%)$ as the observer perspective. These frequencies and percentages among men were $18(72 \%)$ and $7(28 \%)$ for the field and observer perspectives, respectively.

\section{Instruments}

Test Anxiety Inventory (TAI). The TAI (Spielberger, 1980) is a 4-point Likert-type self-report with 20 items designed to assess the general frequency of anxiety experienced in test situations. In this study, the Turkish adaptation of TAI was used. The Turkish version of the scale evidenced satisfactory reliability and validity (Öner, 1986, 1990). In the present study Cronbach alpha coefficient of the TAI was very high $(\alpha=.95)$.

State-Trait Depression Inventory (STDI). This 20 items 4-point Likert-type self-report inventory was originally developed by Spielberger, Ritterband, Rheiser, \& Brunner (2003), and adapted to Turkish by Özer and Özer (2006). The individual is asked to indicate how he/she feels "at the moment" on the State-depression subscale and "in general" on the Traitdepression subscale. In the current study only the Trait subscale of the measure was used. Analysis revealed satisfactory reliability and validity for the STDI, with a high internal consistency coefficient of the Trait subscale in college students $(\alpha=.85)$ (Özer \& Özer, 2006). In the present study Cronbach alpha coefficient of the Trait subscale was similarly high $(\alpha=.87)$.

State-Trait Anger Scale (STAS). This 4-point Likert type self-report scale was originally developed by Spielberger (1980). The subject is asked to rate each anger item as applied to himself/herself "in general" on the Trait-anger subscale and "at the moment" on the State-anger subscale of the measure. In the current study only the Trait subscale of the measure that was adapted to Turkish by Özer (1994) was used. Analysis revealed satisfactory psychometric properties for the Trait subscale, with an internal consistency coefficient in the acceptable range $(\alpha=.80)$. Cronbach alpha coefficient of the Trait subscale $(\alpha=.84)$ was found to be slightly higher in the present study.

Experimental Apparatus. Thought Technology's BioGraph Procomp Infiniti encoder and its Physiological Suite software were used in recording heart rate from blood pressure volume (BVP-HR) and surface electromyography (sEMG). In order to measure BVP, interbeat interval, heart rate and amplitude of BVP Flex/Pro sensor (SA9308M) was used. The 
sensor, which reflects a relative measure of BVP was held press against the palmar surface of the middle finger of the dominant hand with a strap. Heart rate from BVP means were used in this study. The surface EMG data was collected from the frontalis area. Single strip self adhesive electrodes (T3404) were placed across the forehead, reference electrode in the center, active electrode above the iris of the eyes. The sensor (SA9401M-50), bandwidth of $20 \mathrm{~Hz}-500 \mathrm{~Hz}$, was snapped on the electrodes with the extender cables. The sEMG mean was employed in this study.

\section{Procedure}

Recruitment Procedure. A total of 732 undergraduate students were administered a battery of tests consisting of TAI, and Trait subscales of STDI and STAS. They were informed that (1) they were taking part in a study exploring the relationship between imagination and emotions and (2) the first phase of the study would be the completion of the battery of tests. They were told that the research assistants would contact them later for the second phase of the study. The participants were insured that no personal information would be disclosed and that the results of the study would focus on the general tendencies and properties of the participants. Following these explanations and instructions, they were asked to sign a consent form including the information above. The participants fitting to the selection criteria were contacted by phone or email and invited to participate in the study.

Experimental Procedure. The experimental phase of the study was conducted in a completely sound proof room within the clinical psychology laboratory. Participants were seated at one corner of the length of the room in an armchair in such a position that they faced the wall at the other end of the room. The experimenter was positioned about 3 meters away from the participants facing the wall opposite to the participants'. The recording apparatus was placed on a small table near the participant and measures recorded by the apparatus were conveyed to a computer in front of the experimenter by a fiber optic cable.

Phase 1: Briefing on Field and Observer Perspectives - Each subject was seated and the sensors and electrodes were connected to the dominant hand. Then they were informed that the purpose of the study was to explore the relationship between imagination and the emotion of test anxiety and briefed on the field and observer perspectives of imagery._In order to eliminate the possible order effect, the sequence of the information regarding the imagery perspective was shifted to observer-field for every other participant.

Phase 2: Preparation for Physiological Measurement and Signal Verification - After informing and familiarizing the participants on imagery perspectives, the experimenter made sure the sensors were working appropriately. A headphone was placed and the participants were informed that the rest of the instructions would be given through the headphone.

Phase 3: Pre-test Instruction and Measurement - After verifying the signals from the sensors, the participants were instructed to sit comfortably and count down from 50 to 1 by matching each count with exhalation. The pre-test measurement lasted for 120 seconds. The instructions were reminded at the $60^{\text {th }}$ second.

Phase 4: Imagery Instructions and Measurement - The participants were asked to remember and an exam in which they experienced very high levels of anxiety and to imagine that exam. During the 120 second measurement period, the participant was reminded to continue imagining this exam situation at the $40^{\text {th }}$ and $80^{\text {th }}$ seconds.

Phase 5: Determination of Imagery Perspective - Following the imagery measurement in the previous phase, the experimenter asked the participants out loud to indicate which perspective was used during the imagination. 
Phase 6: Instructions for and Measurement in Perspective Shift - If the participant's original imagery perspective was field, he/she was instructed to imagine the same exam from an observer perspective. If the participant's original imagination was from an observer perspective, he/she was instructed to shift the imagination to the field perspective .The instructions were reminded at the $40^{\text {th }}$ and $80^{\text {th }}$ seconds of the phase which lasted for 120 seconds.

Phase 7: Shifting Back to Original Perspective and Measurement - Participants were instructed to shift back to the original perspective in their imagination of the exam. The instruction of original perspective in imagination was repeated at the $40^{\text {th }}$ and $80^{\text {th }}$ seconds of the 120 seconds long session.

Phase 8: Post-test Instructions and Measurement - After the completion of imagery shift, the participants were instructed again to count down from 50 to 1 as they sat in the chair. The instruction was repeated at the $60^{\text {th }}$ second of the post test phase that lasted for 120 seconds.

\section{Results}

Prior to main analyses, participants who originally initiated the imagination with field perspective (fielders) and participants who originally initiated with observer perspective (observers) were compared in terms of self-report measures of TAI, and Trait subscales of STDI and STAS in order to check further differences other than the imagination perspective they used. Independent t-test results indicated that these fielders and observers do not differ statistically from each other in test anxiety, trait depression and trait anger scores before the experimental process.

The data collected from 47 subjects who participated in the experiment were analyzed to observe if there were gender differences. The data presented in Table 1 depict the means, standard errors, and F values of HR from BVP and sEMG collapsed over the five experimental phases for females and males. The data were subjected to two different 2 (gender: Male and Female) by 5 (experimental phases: Pre-test, Original, Change, Back, and Post-test) Mixed Design Factorial ANOVA with a repeated measure on the last factor, that were separately ran for fielders and observers. As seen in Table 1, there were no significant gender differences for HR from BVP and sEMG in the Field group. In the Observer group, females had significantly higher sEMG $(M[S D]=6.35[.80])$ than the sEMG found in males $(M[S D]=2.79[.90]), F(1,14)=8.77, p<.01$. 
Table 1. Means, Standard Errors, and F Values of the Physiological Measures Obtained for Females and Males who Originally Started with Field and Observer Perspectives in the Imagery of Test Anxiety

\begin{tabular}{|c|c|c|c|c|c|c|c|}
\hline \multirow[b]{3}{*}{ Variables } & \multicolumn{4}{|c|}{ FIELD $(n=31)$} & \multirow[b]{3}{*}{ df } & \multirow[b]{3}{*}{$\mathrm{F}$} & \multirow[b]{3}{*}{ Partial $\eta^{2}$} \\
\hline & \multicolumn{2}{|c|}{$\begin{array}{c}\text { Female } \\
(n=13)\end{array}$} & \multicolumn{2}{|c|}{$\begin{array}{c}\text { Male } \\
(\mathrm{n}=18) \\
\end{array}$} & & & \\
\hline & $\mathrm{M}$ & $\mathrm{SE}$ & $\mathrm{M}$ & $\mathrm{SE}$ & & & \\
\hline HR from BVP & 88.37 & 4.04 & 87.27 & 3.43 & 1,29 & .04 & .001 \\
\hline \multirow[t]{3}{*}{ sEMG } & 5.50 & 1.47 & 5.27 & 1.25 & 1,29 & .01 & .000 \\
\hline & \multicolumn{4}{|c|}{ OBSERVER $(\mathrm{n}=16)$} & & & \\
\hline & \multicolumn{2}{|c|}{$\begin{array}{c}\text { Female } \\
(\mathrm{n}=9)\end{array}$} & \multicolumn{2}{|c|}{$\begin{array}{l}\text { Male } \\
(\mathrm{n}=7)\end{array}$} & & & \\
\hline Variables & $\mathrm{M}$ & $\mathrm{SE}$ & $\mathrm{M}$ & $\mathrm{SE}$ & df & $\mathrm{F}$ & Partial $\eta^{2}$ \\
\hline HR from BVP & 77.82 & 3.34 & 85.56 & 3.79 & 1,14 & 2.35 & .144 \\
\hline sEMG & 6.35 & 0.80 & 2.79 & 0.90 & 1,14 & $8.77 *$ & .385 \\
\hline
\end{tabular}

$* p<.01$

Note: HR from BVP: Heart Rate from Blood Volume Pressure; sEMG: Surface Electomyography.

Due to lack of gender differences in fielders and minor differences in observers, the data were collapsed in terms of gender, and therefore the consecutive analyses were conducted without considering gender as a separate factor. The means and standard deviations of the dependent measures of HR and sEMG for the combined group are presented in Table 2. 
Table 2. Means, Standard Deviations, and F Values of the Physiological Measures Obtained in the Field and Observer Perspective Imagery of Test Anxiety for the Total Group

\begin{tabular}{|c|c|c|c|c|c|c|c|c|c|c|c|c|}
\hline \multirow[b]{3}{*}{ Variables } & \multicolumn{10}{|c|}{ Field Perspective $(\mathrm{n}=31)$} & \multirow{3}{*}{$\begin{array}{c}\mathrm{F} \\
(\mathrm{df})\end{array}$} & \multirow{3}{*}{$\begin{array}{c}\text { Partial } \\
\eta^{2} \\
\end{array}$} \\
\hline & \multicolumn{2}{|c|}{ Pre-test } & \multicolumn{2}{|c|}{ Original } & \multicolumn{2}{|c|}{ Change } & \multicolumn{2}{|c|}{ Back } & \multicolumn{2}{|c|}{ Post-test } & & \\
\hline & M & SD & M & SD & M & SD & $\mathrm{M}$ & SD & M & SD & & \\
\hline \multicolumn{13}{|l|}{ HR from } \\
\hline BVP & 88.87 & 15.95 & 88.79 & 14.06 & 86.54 & 14.58 & 87.59 & 14.31 & 86.87 & 14.74 & \multirow{2}{*}{$\begin{array}{c}2.38^{*} \\
(4,120) \\
3.67^{* *} \\
(4,120)\end{array}$} & .073 \\
\hline sEMG & 4.63 & 4.93 & 5.41 & 5.54 & 5.52 & 5.80 & 6.17 & 6.09 & 5.10 & 4.58 & & .109 \\
\hline \multicolumn{13}{|c|}{ Observer Perspective $(\mathrm{n}=16)$} \\
\hline & \multicolumn{2}{|c|}{ Pre-test } & \multicolumn{2}{|c|}{ Original } & \multicolumn{2}{|c|}{ Change } & \multicolumn{2}{|c|}{ Back } & \multicolumn{2}{|c|}{ Post-test } & & \\
\hline Variables & $\mathrm{M}$ & SD & $\mathrm{M}$ & SD & $\mathrm{M}$ & SD & $\mathrm{M}$ & SD & $\mathrm{M}$ & SD & $(\mathrm{df})$ & $\eta^{2}$ \\
\hline $\begin{array}{l}\text { HR from } \\
\text { BVP }\end{array}$ & 80.95 & 13.01 & 83.17 & 10.72 & 81.48 & 9.88 & 81.19 & 9.71 & 79.23 & 12.71 & $\begin{array}{c}1.41 \\
(4,60)\end{array}$ & .086 \\
\hline sEMG & 4.54 & 3.19 & 5.05 & 3.96 & 4.79 & 2.50 & 4.71 & 2.25 & 4.87 & 3.35 & $\begin{array}{c}.45 \\
(4,60)\end{array}$ & .029 \\
\hline
\end{tabular}

$* p<.05 ; * * p<.01$

Note: HR from BVP: Heart Rate from Blood Volume Pressure; sEMG: Surface Electromyography.

\section{Heart Rate from Blood Volume Pressure (HR from BVP)}

Figure 1 displays the trend of the HR means across the experimental phases for the fielders and observers.

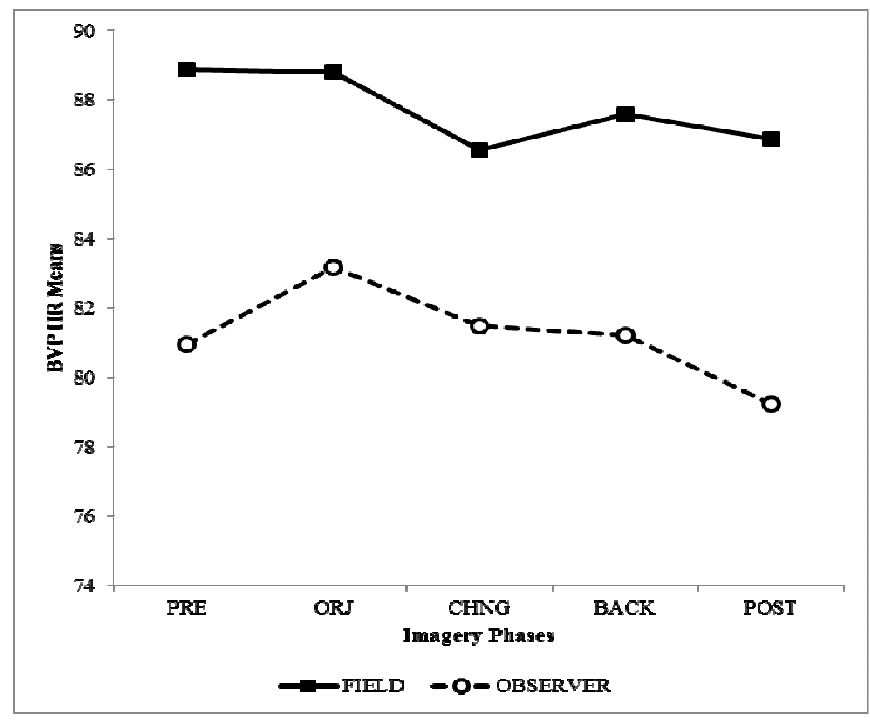

Figure 1. Means of Heart Rate in the Imagery of Test Anxiety across Experimental Phases for Fielders and Observers 
A 2 (original perspective: Field and Observer) by 5 (experimental phases: Pre-test, Original, Change, Back, and Post-test) Mixed Design Factorial ANOVA with a repeated measure on the last factor was carried out in order to see whether the HR means for the fielders and observers were statistically significant. Although an inspection of Figure 1 portrays the means of the fielders to be higher than the observers across all experimental phases, the mean differences between fielders $(M[S E]=87.73[2.37])$ and observers $(M[S E]$ $=81.21$ [3.29]) were found as non-significant, $F(1,45)=2.59, p>.05$.

Table 3. Comparison of the 5 Phases of the Physiological Measures Obtained in the Field and Observer Perspective Imagery of Test Anxiety

\begin{tabular}{|c|c|c|c|c|c|c|c|}
\hline & \multicolumn{2}{|c|}{ Field $(n=31)$} & \multicolumn{2}{|c|}{ Observer $(n=16)$} & \multirow[t]{2}{*}{$\mathrm{df}$} & \multirow[t]{2}{*}{$\mathrm{F}$} & \multirow[t]{2}{*}{$\begin{array}{c}\text { Partial } \\
\eta^{2} \\
\end{array}$} \\
\hline $\begin{array}{l}\text { Experimental } \\
\text { Phases }\end{array}$ & $\mathrm{M}$ & $\mathrm{SE}$ & $\mathrm{M}$ & $\mathrm{SE}$ & & & \\
\hline Pre-test & & & & & & & \\
\hline $\begin{array}{r}\text { HR from BVP } \\
\text { sEMG }\end{array}$ & $\begin{array}{c}88.87 \\
4.63\end{array}$ & $\begin{array}{l}2.87 \\
0.89\end{array}$ & $\begin{array}{c}80.95 \\
4.54\end{array}$ & $\begin{array}{l}3.25 \\
0.80\end{array}$ & 1,45 & $\begin{array}{c}2.924 \\
.005\end{array}$ & $\begin{array}{l}.061 \\
.000\end{array}$ \\
\hline Original & & & & & & & \\
\hline $\begin{array}{r}\text { HR from BVP } \\
\text { sEMG }\end{array}$ & $\begin{array}{c}88.79 \\
5.41\end{array}$ & $\begin{array}{l}2.53 \\
1.00\end{array}$ & $\begin{array}{c}83.17 \\
5.05\end{array}$ & $\begin{array}{l}2.68 \\
0.99\end{array}$ & 1,45 & $\begin{array}{l}1.958 \\
.053\end{array}$ & $\begin{array}{l}.042 \\
.001\end{array}$ \\
\hline Change & & & & & & & \\
\hline $\begin{array}{r}\text { HR from BVP } \\
\text { sEMG }\end{array}$ & $\begin{array}{c}86.54 \\
5.52\end{array}$ & $\begin{array}{l}2.62 \\
1.04\end{array}$ & $\begin{array}{c}81.48 \\
4.79\end{array}$ & $\begin{array}{l}2.47 \\
0.63\end{array}$ & 1,45 & $\begin{array}{c}1.551 \\
.227\end{array}$ & $\begin{array}{l}.033 \\
.005\end{array}$ \\
\hline Back & & & & & & & \\
\hline $\begin{array}{r}\text { HR from BVP } \\
\text { sEMG }\end{array}$ & $\begin{array}{c}87.59 \\
6.17\end{array}$ & $\begin{array}{l}2.57 \\
1.09\end{array}$ & $\begin{array}{c}81.19 \\
4.71\end{array}$ & $\begin{array}{l}2.43 \\
0.56\end{array}$ & 1,45 & $\begin{array}{c}2.576 \\
.858\end{array}$ & $\begin{array}{l}.054 \\
.019\end{array}$ \\
\hline $\begin{array}{l}\text { Post-test } \\
\text { HR from BVP } \\
\text { sEMG }\end{array}$ & $\begin{array}{c}86.87 \\
5.10\end{array}$ & $\begin{array}{l}2.65 \\
0.82\end{array}$ & $\begin{array}{c}79.23 \\
4.87\end{array}$ & $\begin{array}{l}3.18 \\
0.84\end{array}$ & 1,45 & $\begin{array}{c}3.105 \\
.034\end{array}$ & $\begin{array}{l}.065 \\
.001\end{array}$ \\
\hline
\end{tabular}

Note: HR from BVP: Heart Rate from Blood Volume Pressure; sEMG: Surface Electromyography.

\section{HR from BVP Mean Variations across Experimental Phases for Fielders}

The means of the fielders were examined by One-way Repeated Measure ANOVA. As seen in Table 2, the result indicated a significant experimental phase main effect, $F(4,120)=$ $2.38, p<.05$. Post hoc comparisons using the Fisher LSD test at .05 alpha level indicated that for the fielders, the mean obtained in the "original" phase $(M[S E]=88.79$ [2.53]) decreased significantly in the "change" phase $(M[S E]=86.54$ [2.62]) wherein the test anxiety was visualized from an observer perspective. When the fielders were asked to shift back to the field perspective in the "back" phase, the HR mean $(M[S E]=87.59$ [2.57]) increased significantly as compared to "change" phase. Finally, the mean in the "original" phase was also significantly higher than the post-test mean $(M[S E]=86.87[2.65])$.

\section{HR from BVP Mean Variations across Experimental Phases for Observers}

One-way Repeated Measure ANOVA did not reveal a significant experimental phase main effect for observers, $F(4,60)=1.41, p>.05$ (Table 2). 


\section{Surface Electromyography}

The sEMG means of the fielders and observers for each experimental phase are shown in Figure 2.

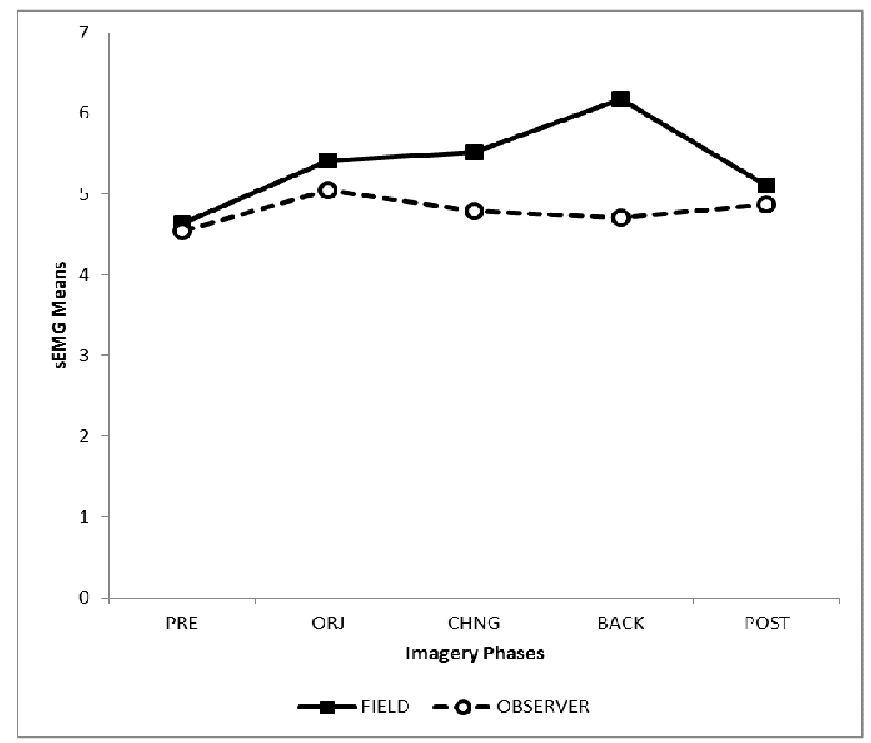

Figure 2. Means of Surface Electromyography in the Imagery of Test Anxiety across Experimental Phases for Fielders and Observers

As can be observed, the sEMG means obtained by the fielders were especially higher than the ones obtained by the observers in the experimental phases except the pre- and posttest phases. However, a 2 (original perspective: Field and Observer) by 5 (experimental phases: Pre-test, Original, Change, Back, and Post-test) Mixed Design Factorial ANOVA with a repeated measure on the last factor indicated that the group means of fielders $(M[S E]$ $=5.37[.82])$ and observers $(M[S E]=4.79[1.15])$ were statistically not significant, $F(1,45)=$ $.17, p>.05$. In addition, as seen in Table 3, the five separate One-way Between Subjects ANOVAs conducted for the comparison of the fielders and observers on each experimental phase did not point out any statistically significant differences either.

\section{sEMG Mean Variations across Experimental Phases for Fielders}

The trend of the sEMG means of fielders exhibited throughout the experimental phases was examined by a One-way Repeated Measure ANOVA. As depicted in Table 2, the result indicated a significant experimental phase main effect, $F(4,120)=3.67, p<.01$. Further Post hoc comparisons using the Fisher LSD test at .05 alpha level pointed out that the means obtained in the "original" $(M[S E]=5.41[1.00])$, "change" $(M[S E]=5.52[1.04])$, and "back" $(M[S E]=6.17$ [1.09]) phases were significantly higher than the "pre-test" phase mean $(M[S E]=4.63[.89])$. The effect of shifting from the original field to an observer perspective was negligible. However, as can be seen in Figure 2, shifting back to the field perspective from the "change" phase wherein imagination was carried out from the observer perspective produced a notable increase in the sEMG mean. Furthermore, the LSD comparisons showed that the sEMG level observed in the "back" phase was significantly higher than the ones observed in the "original", "pre-test", and "post-test" $(M[S E]=5.10[.82])$ phases. 


\section{sEMG Mean Variations across Experimental Phases for Observers}

One-way Repeated Measure ANOVA did not reveal a significant experimental phase main effect for the observer group, $F(4,60)=.45, p>.05$ (Table 2 ).

\section{Discussion}

The main objective of the present study was to explore the process of emotional change as a function of perspective shift in imagery. Test anxiety was chosen as the emotion to be studied. Although mental imagery and perspective in imagery have been a major focus of attention for the past few decades, physiological measurement of the effects of perspective shift seems to be lacking as pointed out by Kross et al. (2005) and Holmes and Mathew (2008). The present study can be considered as an attempt to fulfill the need to establish the effects of perspective shift on emotions assessed by physiological measures of heart rate and surface electromyography.

The results clearly indicated that perspective shift had a main effect on the experience of test anxiety as measured by HR and sEMG only for those who originally started imagery from a field perspective. The shifting effects were clearer with respect to HR. Although the HR levels for the fielders in the "pre-test" and "original" phases were not significantly different, shifting to an observer perspective resulted in significant decreases in HR. Moreover, when the fielders were asked to shift back to the original field perspective, their heart rates displayed significant increases. This can be regarded as clear evidence for the impact and roles of field and observer perspectives in intensifying and decreasing the experience of test anxiety, respectively.

With respect to sEMG, effects of shifting were not as clear as HR. Those initiating their imagery with a field perspective did not reflect any significant change in sEMG after shifting to an observer perspective. However, once they shifted back to the field perspective their sEMG increased significantly as compared to the phase wherein they originally imagined from a field perspective. A possible explanation as to the inability to duplicate the sEMG results with that of HR rate might be the relatively slower reactivity of sEMG as compared to HR and that the 2 minute phase duration was not long enough to capture the effects of perspective shift on sEMG.

The finding that shifting from field to observer perspective resulted in reduced HR levels is consistent with the studies of Robinson and Swanson (1993) and Berntsen and Rubin (2006), which reported that in recalling recent emotional events, when shifting from field to observer perspective, ratings of the emotion are reduced. This particular study might be regarded as adding a further finding that shifting back to field from observer perspective increases HR and sEMG only in those who start imagery with a field perspective.

Data gathered in this study failed to confirm a main perspective shift effect in those participants who initiated their imagery from an observer perspective. Although not significant, this group displayed lower levels of $\mathrm{HR}$ and sEMG compared to fielders throughout the experimental phases and did appear to be effected by any perspective shift.

The finding that the effects of perspective shift was only evident for the fielders and that the observers remained unaffected might yield to a speculation that "perspective disposition" could be a personality trait likely to play a crucial role in the acquisition, maintenance and alleviation of certain emotional problems and dispositions (Holmes \& Mathews, 2010). It would be plausible suggestion that further research explore the possible interaction of perspective disposition and being high or low in emotional dispositions. However, another possible explanation for lack of significant finding in observers may be the small sample size of the observer group $(n<30)$ compared to the field group $(n=31)$. 
Another limitation of the present study regarding the sample size resulted in insufficient gender comparisons. The results showed no significant gender differences in HR and sEMG measures in fielders. However, in observers, although there was no significant gender difference in HR measure, females had significantly higher sEMG than males. This gender difference could not be further examined in the present study due to small sample size in experimental groups, but needs special attention for further research.

Beyond the sample size limitation, the present study has important clinical implications. Imagery has been utilizing in psychotherapy as an intervention tool for a long time for visual processing of emotional material. However, imagery perspective of the recalled memory or imagined situation has not been taken into account in most clinical applications. The present study indicates that effectiveness of imagery based interventions in changing emotional reactions (decrease or increase) may depend on perspective change during the imagery process. Therefore, in clinical applications using imagery as an intervention tool, imagery perspective the client employs needs to be controlled and also manipulated according to the need of the client during the session.

\section{Acknowledgements}

This study was supported by the Scientific and Technological Research Council of Turkey (TUBITAK-SOBAG) Project No: 109KO86

\section{References}

Beck, A. T. (1985). Cognitive therapy, behavior therapy, psychoanalysis, and pharmacology: A cognitive continuum. In M. J. Mahoney \& A. Freeman (Eds.), Cognition and Psychotherapy (pp. 325- 349). New York: Plenum Press.

Bergouignan, L., Lemogne, C., Foucher, A., Longin, E., Vistoli, D., Allilaire, J., \& Fossati, P. (2008). Field perspective deficit for positive memories characterizes autobiographical memory in euthymic depressed patients. Behaviour Research and Therapy, 37, 322333.

Berntsen, D., \& Rubin, D. C. (2006). Emotion and vantage point in autobiographical memory. Cognition and Emotion, 20, 1193-1215.

Bywaters, M., Andrade, J., \& Turpin, G. (2004). Intrusive and non-intrusive memories in a non-clinical sample: The effects of mood and affect on imagery vividness. Memory, 12, 467-478.

Chatterjee, A., \& Southwood, M. H. (1995). Cortical blindness and visual imagery Neurology, 45, 2189-2195.

Coles, M. E., Turk, C. L., Heimberg, R. G., \& Fresco, D. M. (2001). Effects of varying levels of anxiety within social situations: Relationship to memory perspective and attributions in social phobia. Behavior Research and Therapy, 39, 651-665.

D'Argembeau, A., Comblain, C., and van der Linden, M. (2003). Phenomenal characteristics of autobiographical memories for positive, negative, and neutral events. Applied Cognitive Psychology, 17, 281-294.

Dadds, M. R., Bovbjerg, D. H., Redd, W. H., \& Cutmore, T. R. H. (1997). Imagery in human classical conditioning. Psychological Bulletin, 122, 89-103.

Farah, M. J. (1984). The neurological basis of mental imagery: A componential analysis. Cognition, 18, 245-272.

Frank, M. G., \& Gilovich, T. (1989). Effect of memory perspective on retrospective causal attributions. Journal of Personality and Social Psychology, 57, 399-403.

Hackman, A., \& Holmes, E. A. (2004). Reflecting on imagery: A clinical perspective and overview of the special issue of memory on mental imagery and memory in psychopathology. Memory, 12, 389- 402. 
Hirsch, C., Clark, D. M., \& Mathews, A. (2006). Imagery and interpretations in social phobia: Support for the combined cognitive biases hypothesis. Behavior Therapy, 37, 223-236.

Holmes, E. A., \& Mathews, A. (2005). Mental imagery and emotion: A special relationship? Emotion, 5, 489-497.

Holmes, E. A., \& Mathews, A. (2010). Mental imagery in emotion and emotional disorders. Clinical Psychology Review, 30, 349-362.

Holmes, E. A., Mathews, A., Dalgleish, T., \& Mackintosh, B. (2006). Positive interpretation training: Effects of mental imagery versus verbal training on positive mood. Behaviour Therapy, 37, 237-247.

King, D. L. (1973). An image theory of classical conditioning. Psychological Reports, 33, 403-411.

Kosslyn, S. M., Ganis, G., \& Thompson, W. L. (2001). Neural foundations of imagery. Nature Reviews Neuroscience, 2, 635-642.

Kosslyn, S. M., Thompson, W. L., Kim, I. J., \& Alpert, N. M. (1995). Topographical representations of mental images in primary visual cortex. Nature, 378, 496-498.

Kross, E., Ayduk, O., \& Mischel, W. (2005). When asking 'why' does not hurt: Distinguishing from reflective processing of negative emotions. Psychological Science, 16, 709-715.

Lang, P. J. (1979). A bio-informational theory of emotional imagery. Psychophysiology, 16, 495-512.

Lang, P. J. (1985). The cognitive psychophysiology of emotion: Fear and anxiety. In A. H. Tuma \& J. D. Maser (Eds.), Anxiety and the anxiety disorders (pp.131-170). Hillsdale, NJ: Erlbaum.

Lang, P. J., Bradley, M. M., \& Cuthbert, B. N. (1998). Emotion, motivation and anxiety: Brain mechanisms and psychophysiology. Biological Psychiatry, 44, 1248-1263.

Lang, P. J., Melamed, B. G., \& Hart, J. D. (1970). A psychophysiological analysis of fear modification using an automated desensitization procedure. Journal of Abnormal Psychology, 76, 220-234.

Lemogne, C., Piolino, P., Friszer, S., Claret, A., Girault, N., Jouvent, R., Allilaire, J., \& Fossati, P. (2006). Episodic autobiographical memory in depression: Specificity, autonoetic consciousness, and self-perspective. Consciousness and Cognition, 15, 258268.

Libby, L. K., \& Eibach, R. P. (2002). Looking back in time: Self-concept change affects visual perspective in autobiographical memory. Journal of Personality and Social Psychology, 82, 167-179.

Lichstein, K. L., \& Lipshitz, E. (1982). Psychophysiological effects of noxious imagery: Prevalence and prediction. Behavior Research and Therapy, 20, 339-345.

Mahoney, M. J. (1993). Theoretical developments in the cognitive psychotherapies. Journal of Consulting and Clinical Psychology, 61, 187-193.

Mathews, A., \& MacLeod, C. (2002). Induced processing biases have causal effects on anxiety. Cognition and Emotion, 16, 331-354.

McIsaac, H. K., \& Eich, E. (2004). Vantage point in traumatic memory. Psychological Science, 15, 248-253.

Miller, G. A., Levin, D. N., Kozak, M. J., Cook, E. W., McLean, A., \& Lang, P. J. (1987). Individual differences in imagery and the psychophysiology of emotion. Cognition and Emotion, 1, 367-390.

Nigro, G., \& Neisser, U. (1983). Point of view on personal memories. Cognitive Psychology, $15,467-482$. 
O’Craven, K. M., \& Kanwisher, N. (2000). Mental imagery of faces and places activates corresponding stimulus-specific brain regions. Journal of Cognitive Neuroscience, 12, 1013-1023.

Öhman, A., \& Mineka, S. (2001). Fears, phobias, and preparedness: Toward an evolve module of fear and fear learning. Psychological Review, 108, 483-522.

Öner, N. (1986, April). Development of the Turkish form of the Test Anxiety Inventory. Paper presented at the International Symposium on Test Anxiety. AERA Annual Meeting, San Francisco, CA.

Öner, N. (1990). Sinav Kaygisı Envanteri Elkitabı [Manual for the Test Anxiety Inventory]. Istanbul: Yöret Yayınları.

Özer, A. K. (1994). Sürekli Öfke (SL-Öfke) ve Öfke İfade Tarzı (Öfke-Tarz) Ölçekleri ön çalışması [Preliminary study of Trait Anger and Anger Expression Scales]. Türk Psikoloji Dergisi, 9, 26-35.

Özer, A., \& Özer, S. (2006). Durumsal-Sürekli Depresyon Ölçeği’nin faktöriyel alt yapısı [Factorial structure of the State-Trait Depression Inventory]. Doğuş Üniversitesi Dergisi, 7, 210-217.

Robinson, J. A., \& Swanson, K. L. (1993). Field and observer modes of remembering. Memory, 1, 169-184.

Schacter, D. L., Addis, D. R., \& Buckner, R. L. (2007). Remembering the past to imagine the future: The prospective brain. Nature Reviews Neuroscience, 8, 657-661.

Spielberger, C. D. (1980). Test Anxiety Inventory. Preliminary professional manual. Palo Alto, CA: Consulting Psychologists Press.

Spielberger, C. D. (1980). Preliminary manual for State-Trait Anger Scale (STAS). Tampa, FL: Psychological Assessment Resources.

Spielberger, C. D., Ritterband, L. M., Reheiser, E. C., \& Brunner, T. M. (2003). The nature and measurement of depression. International Journal of Clinical and Health Psychology, 3, 209-234.

Spurr, J., \& Stopa, L. (2003). The observer perspective: Effects on social anxiety and performance. Behaviour Research and Therapy, 41, 1009-1028.

Sutin, A. R., \& Robins, W. R. (2008). When the "I" looks at the "Me": Autobiographical memory, visual perspective, and the self. Consciousness and Cognition, 17 (4), 13861397.

Wells, A., Clark, D. M., \& Ahmad, S. (1998). How do I look with my minds eye: Perspective taking in social phobic imagery. Behaviour Research and Therapy, 36, 631-634.

Vrana, S. R., Cuthbert, B. N., \& Lang, P. J. (1986). Fear imagery and text-processing. Psychophysiology, 23, 247-253. 